\title{
Parcelized Cut-and-Carry Agroforestry Systems for Confined Livestock
}

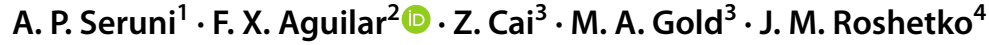

Accepted: 5 September 2020 / Published online: 16 September 2020

(c) The Author(s) 2020

\begin{abstract}
We characterize a parcelized land management system that does not meet traditional co-located agroforestry practices in the tropics. A cut-and-carry agroforestry system for confined livestock emphasizes land utilization as a source of fodder, cutting and carrying feed from parcels to paddocks near a farmer's home. It reduces feed cost by utilizing parcels under private, shared, and/or public ownership. Within cut-and-carry systems, we distinguish between those where parcels are managed as monocrops and traditional co-located agroforestry practices. Primary data for our case study were collected by surveying heads of household in Central Java, Indonesia, and analyzed following a capitals-based rural livelihoods framework. A sample of 122 farmers who managed parcels under co-located agroforestry practices was compared against 50 farmers who implemented parcelized monocropping. Overall, the adoption of cut-and-carry systems supports financial resiliency by limiting cash expenditures, facilitating income diversification, and producing assets that meet planned market opportunities and unforeseen cash needs. Survey results show that farmers who engage in parcelized agroforestry have more farming experience, higher farming income, are located at higher elevations, and live farther from the nearest local market. On-farm income among agroforestry cut-and-carry farmers was on average $11.1 \%$ higher than those using a cut-and-carry system but only adopting monocrop practices. Land as a biophysical capital asset under full privateownership and at higher altitudes, and longer farming experience as a human capital asset, increased the likelihood of adopting parcelized co-located agroforestry practices. Membership in cash-crop cooperatives as a form of social capital asset was associated with a higher likelihood of managing land as parcelized monocrops.
\end{abstract}

Keywords Agroforestry · Woodlot - Smallholder · Logistic regression · Propensity score matching $\cdot$ Indonesia

F. X. Aguilar

Francisco.aguilar@slu.se

Extended author information available on the last page of the article 


\section{Introduction}

Agroforestry has long been heralded as a land management system suitable to support rural livelihoods, adapt to a changing climate, diversify revenue sources, and cope with risk (McCabe 2013). In Indonesia, agroforestry has been actively promoted for over 30 years as a low-cost land use system beneficial to smallholder farmers. According to Sabrani and Saepudin (1994) bottomland agronomic systems that integrate tree planting with livestock are widely adopted and effectively contribute to farmers' enhanced income in Indonesia's Central Java region. Silvopastural practices have also been adopted in upland agriculture to promote soil conservation by planting nitrogen-fixing and fodder producing trees (e.g. Gliricidia sepium and Calliandra calothyrsus) in terrace systems. In addition to silvopastural practices (Alavalapati et al. 2004), home gardens (Sabastian et al. 2014; Roshetko et al. 2013), and riparian buffer strips (Anbumozhi et al. 2005) are the most commonly adopted agroforestry practices in Indonesia.

Agroforestry practices are frequently adopted within the same lot as in the case of silvopastures, intercrops or live fences, but their co-location is not necessary for land to be managed as an agroforestry system. Agroforestry systems can be parcelized as different practices may be implemented in separate lots-yet integrated over a larger landscape through resource management. Haines and McFarane (2007) defined parcelization as a rural landscape process of dividing a larger area of land into smaller lots. Partly because of parcelization, landscapes can be ecologically fragmented by having different land uses between plots and across ownerships. As suggested by Fujiwara et al. (2018) decisions to allocate particular management practices to different parcels are often driven by site conditions (e.g., topography, soil fertility) and land tenure considerations (e.g., individual- or group-ownership, leased). In addition, farmers' adoption of agroforestry practices, and tree planting decisions specifically, has been influenced by available agricultural technologies in response to declining soil quality and household labor supply, government policies, national reforestation programs, among other reasons (van Der Poel and van Dijk 1987; Nibbering1999).

In this manuscript, we describe a land management system that does not meet traditional co-located agroforestry characteristics. Our first objective is to offer a detailed characterization of cut-and-carry agroforestry systems that integrate land management between parcels. Our second objective is to, within cut-and-carry systems, identify differences between farmers engaged in parcelized agroforestry and monocrop practices. The manuscript starts by describing our case study area in Central Java's Gunung Kidul and characterizing parcelized smallholder cut-and-carry agroforestry systems for confined livestock. We outline our theoretical framework for data collection and analysis based on a capitals-based approach to appraise rural livelihoods. We relied on statistical analyses to determine statistically significant differences in cut-and-carry systems between landowner sub-groups adopting parcelized agroforestry and monocrop practices. We also assess the financial performance between these two sub-groups. We offer various insights regarding cut-andcarry systems and point to areas that merit future investigation. 


\section{Parcelized Cut-and-Carry Systems with Confined Livestock in Gunung Kidul}

Gunung Kidul is one of five districts in the Yogyakarta region, with a population of 704,000 people located between latitudes $7^{\circ} 460-7^{\circ} 090$ and longitudes $110^{\circ} 210-110^{\circ} 500$ (Statistics of Gunung Kidul Regency 2016). The climate in the Gunung Kidul area is strongly influenced by the wet Northwest monsoon (November-May) and dry Southeast monsoon (June-October) with an average temperature between 24 and $26{ }^{\circ} \mathrm{C}$ (Sudiharjo and Notohadiprawiro 2006). Gunung Kidul has 18 subdistricts and 144 villages with distinct topographic areas receiving annual rainfall of $1500-2500 \mathrm{~mm}$. Approximately $74 \%$ of the district has karsts soils, predominantly in the Sewu mountain range; Vertisols are dominant in the Wonosari plateau. Entisol and Alfisol soil types cover the Baturagung mountain range. Elevation ranges from 0 to $700 \mathrm{~m}$ above sea level (Statistics of Gunung Kidul Regency 2009). Its landscape is hilly along its northern, eastern and southern boundaries (Baturagung and Sewu mountain ranges) and relatively flat in its central zone (Wonosari plateau) with $71 \%$ of the district's area with slopes ranging from 2 to $40 \%$. Our study focused on seven subdistricts including Karangmojo and Playen that represent lowlands (Wonosari), Nglipar and Semin that represent uplands (Baturagung mountain ranges) and Tepus, Panggang and Paliyan that represent mountainous (Sewu) areas (Fig. 1).

Gunung Kidul district is known for persistent deforestation, soil erosion, and widespread poverty (Nibbering 1999; Roshetko et al. 2013). Farming is the main contributor to the district's economy, providing 34\% of gross income and most employment. Within the agricultural sector, food crops (e.g., maize and rice paddy) account for $64 \%$ of economic value, followed by forestry $(27 \%)$, livestock $(6 \%)$, plantation crops (2\%), and fisheries (<1\%) (Rohadi et al. 2011). Sabastian et al. (2014) report that land use allocation in Gunung Kidul consists of dryland systems $(45.3 \%)$, woodlots $(17.3 \%)$, home gardens $(17.1 \%)$, state forests $(8.8 \%)$, wetland farms $(5.3 \%)$, ponds $(0.1 \%)$ and others $(6.2 \%)$. Trees are planted scattered across fields and along contours in smallholder silvicultural systems in both dryland systems (kitren and tegalan) and home gardens (pekarangan).

Farming systems in Gunung Kidul are stratified by elevation. Farmers in upland areas commonly practice agroforestry, cultivating upland rice (Oryza sativa), cassava (Manihot utillisima), maize (Zea mays), occasionally soybean (Glicyine max) and other crops (e.g., banana, ginger, curcuma). In upland areas farmers also plant trees such as mahogany (Swietenia macrophylla), teak (Tectona grandis) and acacia (Acacia auriculiformis). Farmers in low-land areas engage in commodity crops such as rice in paddy systems, cassava, maize, soybean and ground nuts (Arachis hypogaea). Seasonal weather variation affects farmers' decisions to plant cash crops. For instance, rice paddy is established during the March wet season and harvested in July. Cassava is planted in August and harvested after one year. Soybean or ground nuts are planted as a substitute of maize in alternate years. Instead of cassava, farmers also may choose to plant maize in December to be harvested in March/April the following year. In Gunung 


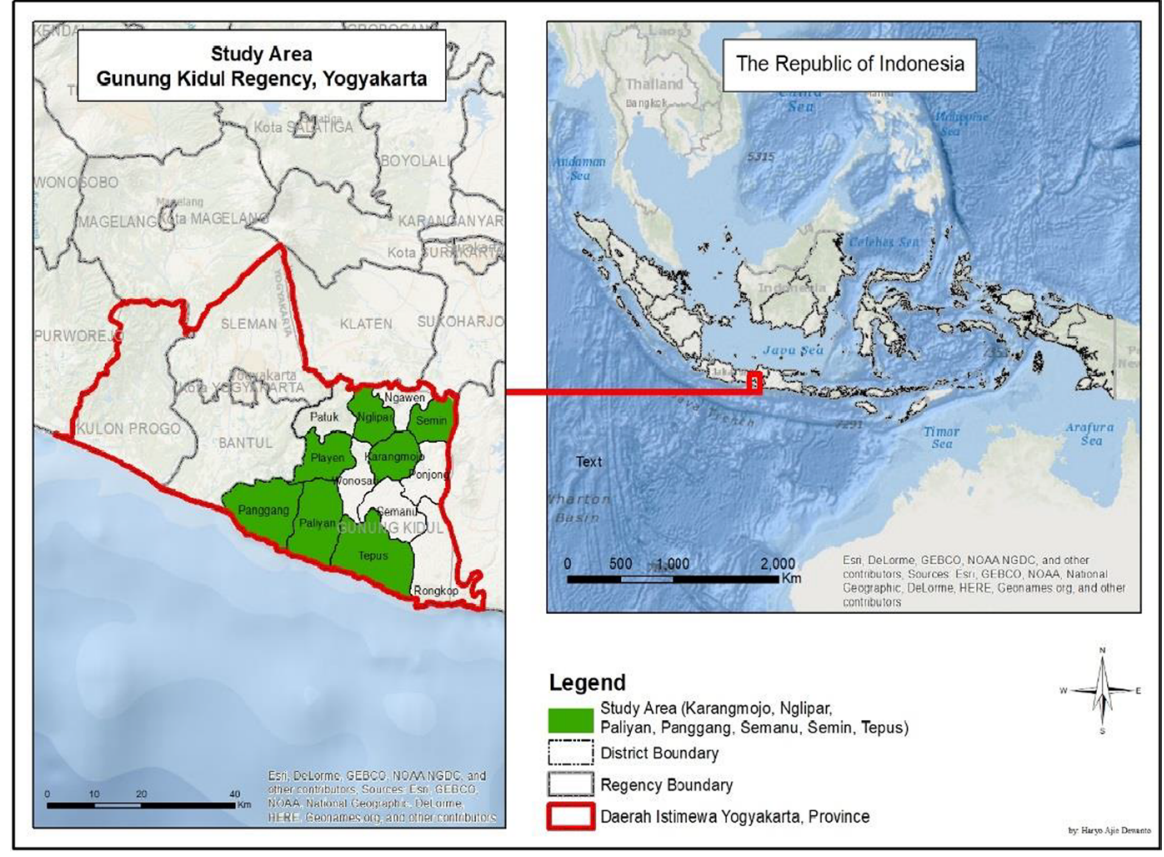

Fig. 1 Study area within Gunung Kidul District, Indonesia. Data source: Central Bureau of Statistics Republic of Indonesia (2016)

Kidul farmers have incorporated tree planting within agricultural crops as a form of capital accumulation (Rohadi et al. 2011) and to improve their livelihoods through low-input land management strategies (Roshetko et al. 2013). Socioeconomic and farm conditions determine the functions trees serve (Fujiwara et al. 2018). Common purposes include wood production, boundary demarcation, canopy for shade-demanding crops, protection against erosion, and shelter. Timber trees may be incorporated in various arrangements and densities in existing farm niches to better serve these particular functions. For instance, timber species are often intercropped or planted in dedicated woodlots (Sabastian et al. 2009).

Gintings and Lai (1994) define a cut-and-carry system as one adopting agrosilvopasture practices where livestock are stall-fed (paddock) with fodder collected from forests, home gardens, and along irrigation channels and even roadsides. In Gunung Kidul, a cut-and-carry system is commonly used to co-manage livestock (e.g., goat, beef cattle), forage, and cash-crops (e.g., maize, paddy, groundnut). Farmers adopt this system to minimize the cost of livestock feed and manage risk. The use of cut-and-carry systems can be found in other parts of the world such as in the Central Highlands of Mexico (Pincay-Figueroa et al. 2016) but their description in the extant literature is scarce. According to Rohadi et al. (2011) farmers commonly allocate $10 \%$ of their land to commercial timber stands (kitren systems), producing teak, acacia, and mahogany. Farmers also integrate timber into mixed upland cropping systems (tegalan) and home gardens (pekerangan). Land is frequently 
parcelized into two or three plots often including (a) a home plot where farmers plant vegetables, some forage, and an enclosure to keep livestock near their home, (b) an agricultural plot for cash crop production, and (c) a state-owned forest plot managed by farmers but publicly owned. The latter plot type is commonly planted with Tectona grandis and Melaleuca spp. Farmers who manage state forestland use the cut-and-carry system because of the inability to grow agricultural crops after the canopy has closed. Alternatively, they establish tree fences as a fodder source including Calliandra calothyrsus, Gliricidia sepium and Leucaena leucocephala and perennial grasses such as Pennisetum purpureum. Farmers cut forage and carry it to a paddock two to three times a day to meet livestock feed requirements. This is an integrated land management system as farmers incorporate livestock manure as organic fertilizer back into other plots (Fig. 2). It also includes diverse types of property right arrangements over different farm resources. The cut-and-carry system is utilized by farmers adopting parcelized agroforestry and monocrop practices.

Farmers in Gunung Kidul manage livestock as a savings and risk-management resource. They buy livestock when they have cash in excess of their immediate demands and sell livestock when in financial need. As a valuable financial asset, livestock is kept near homes as a precautionary risk measure. A profile of how farmers manage their livestock is presented in Table 1. Perdana et al. (2012) suggest that farmers in Gunung Kidul also manage teak as a savings resource that is retained as an asset of last resort after other disposable financial resources are exhausted. The preference for teak seems to be rooted in its initial fast growth and greater timber value than other species. Financial motivations are behind land allocation, too, contingent on tenure rights. For instance, most farmers keep livestock near their house where they enjoy full property rights. However, livestock-related agronomic
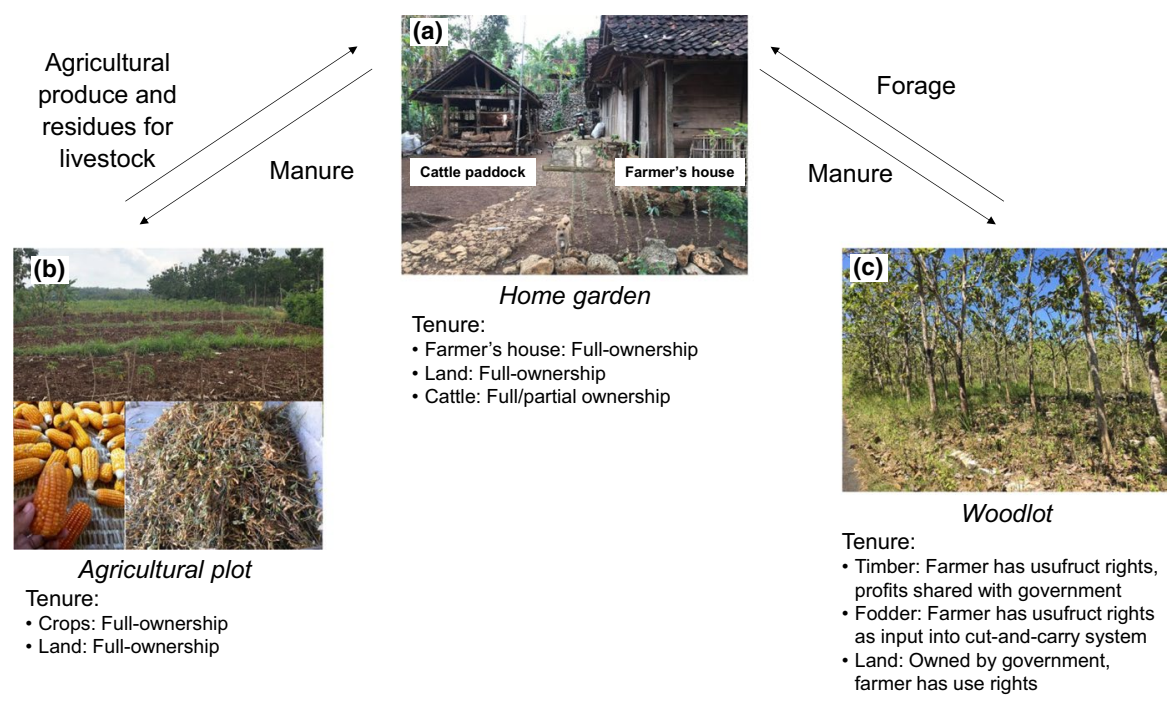

Fig. 2 Cut-and-carry system with a confined livestock, $\mathbf{b}$ cash crop, and $\mathbf{c}$ woodlot parcels. Photo credits: Authors 
Table 1 Characteristics of livestock management systems in Gunung Kidul

\begin{tabular}{|c|c|}
\hline Characteristics & Description \\
\hline Type & Cattle, goat, sheep \\
\hline Functions & $\begin{array}{l}\text { Capital accumulation and liquidation, manure as organic fertilizer, farm work, protein } \\
\text { source for human consumption }\end{array}$ \\
\hline Ownership & $\begin{array}{l}\text { Fully-owned livestock or partially owned livestock (managing under a particular } \\
\text { shared agreement) }\end{array}$ \\
\hline Paddock & In the garden near the farmer's house \\
\hline Feed & Collect feed from farmer's own land but also from communal- and state-owned lands \\
\hline $\begin{array}{l}\text { Husbandry } \\
\text { knowledge and } \\
\text { skills }\end{array}$ & $\begin{array}{l}\text { Knowledge obtained primarily from parents and other ancestors. Influenced by exten- } \\
\text { sion programs intended to improve productivity by introducing new technologies } \\
\text { (e.g. artificial insemination) }\end{array}$ \\
\hline
\end{tabular}

activities on state forestlands are limited to fodder cut-and-carry because farmers do not have full property rights. Furthermore, feed necessary to complement livestock dietary needs is often sourced from home gardens, irrigation channels, and roadsides during the wet season (Gintings and Lai 1994). In the dry season animals are herded on arable lands, and are also fed hay and other crop residues such as corn stover.

\section{Conceptual Framework}

The adoption of land management practices is the result of a farmer's aim to maximize household wellbeing. The decision-making process of smallholder farmers is part of a strategy to balance livelihood objectives, possibilities, and constraints (Van Noordwijk et al. 2001). Farmers continuously select strategies that optimize expected utility derived from the land, trees, family labor, cash and other available resources to meet wellbeing objectives and minimize critical risk factors (Ellis 2000). Specific to agroforestry practices, socioeconomic characteristics such as family size, labor, social capital, land holding size, income, age, and experience reportedly have a systematic effect on the likelihood of their adoption (McGinty et al. 2008). Adesina and Chianu (2002) report that larger family sizes intrinsically provide more labor facilitating the adoption of commonly more labor-intensive agroforestry systems. Land availability can also influence a farmer's decision to adopt agroforestry practices (Adesina and Chianu 2002). Pattanayak et al. (2003) highlights the role of financial resources and infrastructure as cash availability and lesser road accessibility seem to influence farmers' adoption of agroforestry. Adesina and Chianu (2002) found farmer's age and experience to also be associated with the decision to integrate trees into farming systems. Pattanayak et al. (2003) further reported that experience and familiarity of farmers with general farming and tree planting were strongly associated with agroforestry adoption. In addition, Neupane et al. (2002) have suggested that membership in a local organization consistently had a significant and positive effect on farmers' willingness to adopt agroforestry practices. 
We relied on a capitals-based approach to rural livelihoods to examine likely reasons associated with the adoption of agroforestry within cut-and-carry parcelized systems. A rural livelihoods' capitals-based approach offers the benefit of an established conceptual framework suited to the assessment of land management practices. Under this framework, rural livelihoods are comprised of five forms of capital: human, social, financial, natural, and physical (Ellis 1998). Human capital is a combination of knowledge, habits, behavior, and personality that contribute to economic benefits for an individual and/or community (Ellis 1999; 2000). Human capital also includes the health of an individual, household, and community in order to be able to harness other forms of capital (Smith et al. 2001). Coleman (2010) explains that human capital is created by changes to skillsets and capability to act. Human capital is often measured through education attainment (e.g., years of schooling), demographic (e.g., racial and ethnicity) and household characteristics. Social capital refers to relationships, institutions, and norms that shape societal interactions. It plays a significant role in the productivity of an individual, organization, and community (Ellis 2000; Baum and Ziersch 2003). The literature suggests that social capital is commonly gauged through the assessment of social structure, trust, norms, and social networks that facilitate collective action (Green and Haines 2002). Social capital may be proxied through participation in organizations, voluntary associations, newspaper readership but also by assessing individuals' involvement in public meetings, informal sociability, and trust (Ellis 2000). Social capital gains come through changes in relations among people to facilitate shared and coordinated actions (Coleman 2010). Financial capital assets include savings, income, investments, and access to credit. It can be measured through household income, property value, and investments, among other financial assets. Natural capital can be defined as stocks of natural resources that flow to produce ecosystem services sustaining rural livelihoods (Daly et al. 1994). Amongst smallholder farmers their most fundamental and constraining physical asset is land (Missemer 2018). Physical capital refers to the built environment, comprised of a residential housing, public buildings, business/industry, dams and levees, and shelters, among others. It also includes infrastructure that allows access to electricity, water, telecommunications, hospitals, schools, fire and police stations, and nursing homes. Physical capital can be measured by the number, quality, and location of housing units, business/industry, and infrastructure (Ellis 2000). In the context of this research, natural and physical capital assets were jointly captured through land size and ownership information. Henceforth, we jointly refer to these two forms of capitals as bio-physical assets.

\section{Methods}

\section{Survey Instrument and Data Collection}

A survey was developed to gather information about farm and land conditions, farming and market information, and farmers' socio-demographic characteristics. It was first developed in English translated into Indonesian and back to English to ensure consistency (Cai and Aguilar 2013). The survey was pre-tested in Karangmojo 
sub-district prior to deployment following a participatory rural appraisal technique inclusive of group discussions with farming leaders and field observations. The pretest aimed to gather contextual information about farming background and preferences and to corroborate through observation that the commodities selected in the survey were commonly planted. Farm, farming and farmers' characteristics included in the final questionnaire were associated with elements of social, financial, human and bio-physical capitals as summarized in Table 2.

We face-to-face surveyed a total of 172 farmers engaged in cut-and-carry systems. Among them 122 had adopted parcelized agroforestry practices and 50 were engaged in parcelized monocrop farming. The split reflects how a majority of farmers in our study region engaged in parcelized agroforestry. The distinction of two farmer groups was determined on where they obtain fodder or feed for livestock. Parcelized agroforestry farmers primarily obtain feed from forest areas, either from private or state forests. In contrast, parcelized monocrop farmers obtain feed from their own agricultural fields, primarily from border plantings of fodder plants or agricultural residues. The sampling recruitment process is outlined in Fig. 3. Primary household data were collected between May and July 2017. Questionnaires were collected in seven sub-districts: Karangmojo, Tepus, Semanu, Nglipar, Semin, Paliyan and Panggang.

\section{Data Analysis}

In addition to sample descriptive statistics, data analyses included a binary regression to identify systematic differences between monocrop and agroforestry farmers, and financial analyses to compare and contrast cut-and-carry characteristics between parcelized agroforestry and monocrop farming. We also explored the potential causation between parcelized agroforestry and higher farm revenues over monocrop farming. Descriptive statistics included measures of centrality and

Table 2 Survey sections, livelihood capitals, and selected farm and farmers characteristics

\begin{tabular}{lll}
\hline Section & Capitals & Characteristics (variables) \\
\hline Farming and Market Information & Social & Cash-crop cooperative membership \\
& Social & Distance to nearest market \\
Farm and Land Characteristics & Human & Number of available farm laborers \\
& Financial & Livestock owned, measured in animal \\
& Bio-physical/Financial & Land size \\
& Bio-physical/Financial & Land ownership \\
& Bio-physical & Elevation \\
& Financial & Commodity and timber crops \\
& Human & Age \\
& Human & Head of household education \\
& Human & Farming experience \\
& Financial & On-farm income \\
\hline
\end{tabular}




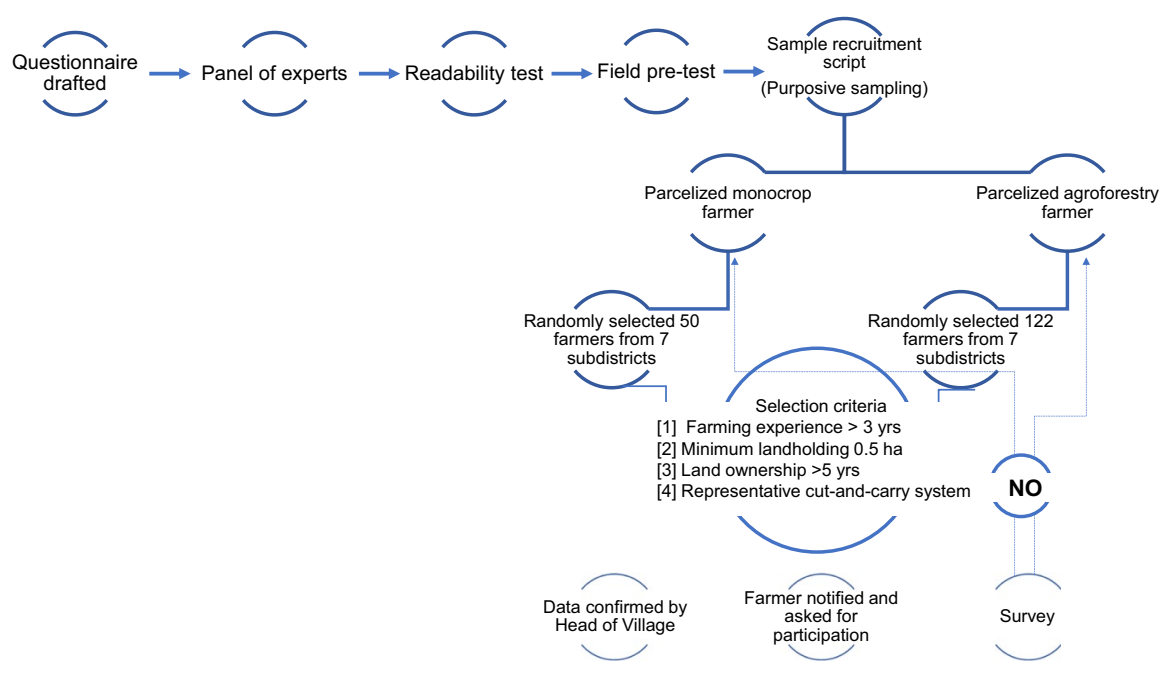

Fig. 3 Sampling recruitment process of survey respondents based on selection criteria of the farmers

distribution and differences in means of agroforestry and monocrop agricultural farmer groups. Logistic regression examined the relationship between selected covariates and the adoption of parcelized agroforestry. Here, the dependent variable was adoption of parcelized agroforestry (0: 'monocrop' farmers; 1: 'agroforestry' farmers) within cut-and-carry systems. The model included 12 explanatory variables (Table 3). Eight explanatory variables corresponded to farming information, market information, livestock, land size, number of family members who work on the farm, land ownership status, and land elevation. The other four (age, education, years of experience, and on-farm income) controlled for sociodemographic characteristics. We estimated odds ratios to ease interpretation of covariate association (Hosmer et al. 2013).

We implemented a propensity-score one-to-one matching to address the likely non-random nature of engaging in agroforestry, over monocropped, cut-and-carry farming and to examine its possible causal effect on higher on-farm revenue. It consists of a quasi-experimental statistical technique that mimics a randomization process through re-sampling (Dehejia and Wahba 2002) that has been applied in non-experimental causality studies in forest management (Song et al. 2014a, b). We first estimated the probability of a farmer to be in either cut-and-carry category using a logistic regression with the same explanatory variables as used previously but leaving out on-farm income as the outcome response. Our rationale for the selection of variables in the matching step was to control for systematic effects associated with farming and market information, and other resources intrinsic to the owner and her/his land, on the adoption of parcelized agroforestry. Propensity scores from the logistic regression were used to match agroforestry and monocrop farmers one-to-one to then estimate mean differences in on-farm income. All statistical analyses were conduced in Stata version 15.1. 
Table 3 Dependent and independent variables used in logistic regression model to identify differences between parcelized agroforestry and monocrop practices within cut-and-carry systems

\begin{tabular}{|c|c|}
\hline Variables & Description \\
\hline Dependent & $\begin{array}{l}\text { Cut and curry system practice adoption with: } \\
1=\text { Parcelized agroforestry practices } \\
0=\text { Monocrop commodity agriculture }\end{array}$ \\
\hline \multicolumn{2}{|l|}{ Independent } \\
\hline Farming and market information & $\begin{array}{l}\text { Cash-crop cooperative membership: } \\
\text { Respondent participates in cash crop cooperative: } \\
1=\text { Member of cash crop cooperative } \\
0=\text { Not a member of cash crop cooperative } \\
\text { Accessibility to nearest market } \\
\text { Distance from respondent house to market (minutes) }\end{array}$ \\
\hline Farm and land characteristics & $\begin{array}{l}\text { Number of farm laborers: } \\
\text { Number of family members participation as farm labor } \\
1=\text { Number of family members working as farm labor is more than } \\
\text { one } \\
0=\text { Number of family members working as farm labor is one } \\
\text { Livestock owned: } \\
\text { Number of animal units (AUs) owned by household, converted to } \\
\text { the following categories in logistic regression } \\
1=\text { More than } 2 \text { AUs } \\
0=2 \text { or fewer AUs } \\
\text { Land size: } \\
\text { Total area of land managed by household including private, shared } \\
\text { and publicly owned lands } \\
\text { Land ownership status: } \\
\text { Categories denoting land ownership status } \\
\text { Fully-owned: Lland is in full ownership by the respondent, house- } \\
\text { hold can harvest all production from the land } \\
\text { Partially-owned: Land is owned by another party, household has } \\
\text { the right to use and market produce based on established agree- } \\
\text { ments } \\
\text { Shared: Land is owned by more than two households, the cost and } \\
\text { production from the land are commonly divided based on the } \\
\text { number of individuals holding rights to the land } \\
\text { Leased: Land has been leased from/to another person with agree- } \\
\text { ment over how it is to be used } \\
\text { Elevation } \\
\text { Ordered categories capturing regency elevation } \\
3 \geq 300-700 \text { m above sea level } \\
2=200-300 \text { m above sea level } \\
1=0-200 \mathrm{~m} \text { above sea level }\end{array}$ \\
\hline
\end{tabular}


Table 3 (continued)

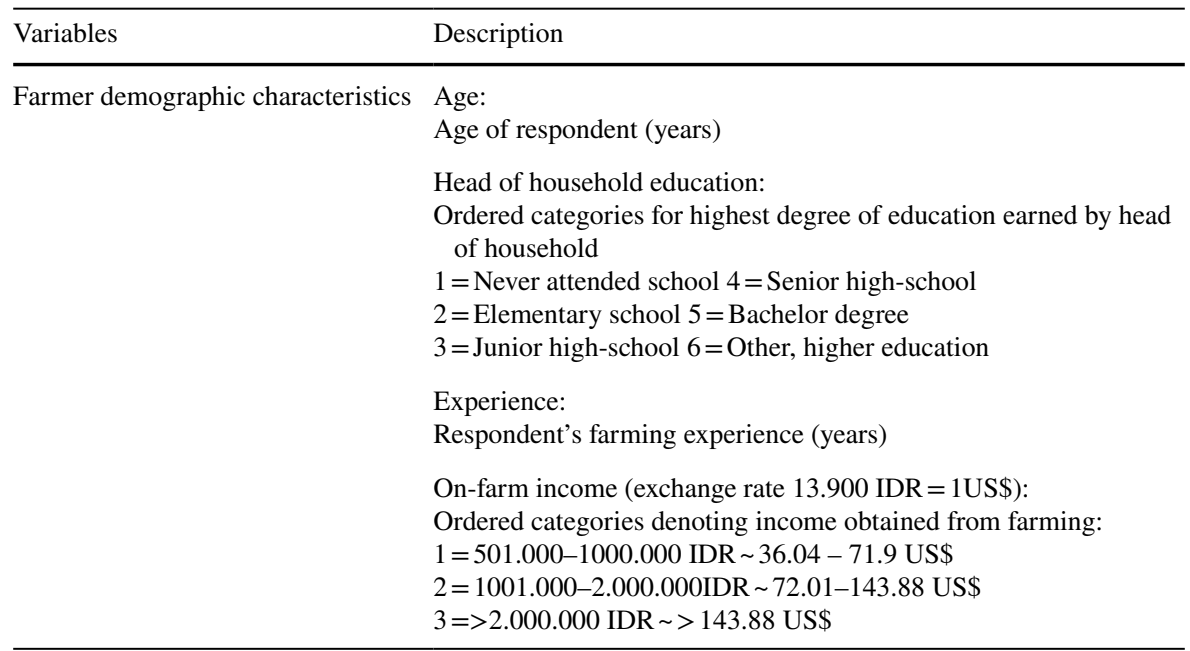

Financial indicators were generated to gather insights into conditions associated with the adoption of parcelized agroforestry practices over lots managed as monocrops. We quantified differences in operational costs, income and net profit margins to assess the relevance of each component to cut-and-carry financial performance (Gittinger 1982; Monke and Pearson 1989). In both cases, profit margins were calculated as the difference between total revenues and costs (inputs, operations, labor, etc.) to assess how production and price of each commodity influenced final farm profitability. The costs of all inputs and operations in a year period are shown in Table 4. Within our estimates we considered a second scenario where farmers engaged in parcelized agroforestry sold livestock periodically (usually every $2-3$ years as per our survey results) to assess its impact on profitability. This scenario was chosen because farmers engaged in agroforestry do not have regular annual income generated from commodity crops, hence, revenues from livestock are needed on a periodic basis to meet households' needs.

Under the cut-and-carry parcelized monocrop system, we estimated the annualized costs and revenues for each crop in dry and wet seasons. We did not consider repayment of capital, taxes or insurance, because farmers did not have any amortization of such payments for an entire year. This latter assumption was empirically supported by the fact that farm insurance and taxes are not mandatory in Indonesia. Farming taxes are not mandatory but farmers have to pay real estate (land and building) taxes every year. Real estate taxation is levied only on land that is under full private ownership commonly ranging from US\$10 to US $\$ 35$ per year. Although in 2013 the Indonesian government proposed legislation (Law No. 19) to protect farmers through agriculture insurance (Law No. 19/2013), most farmers are unaware of it and there is a prevalent lack of understanding regarding its implementation as observed during survey data collection. 
Table 4 Farming costs of selected crops and commonly used inputs (US\$/0.1 ha)

\begin{tabular}{|c|c|c|c|c|c|}
\hline \multirow[t]{2}{*}{ Input/crop } & \multicolumn{2}{|l|}{ Paddy } & \multicolumn{2}{|l|}{ Maize } & \multirow{2}{*}{$\begin{array}{l}\text { Groundnut } \\
\text { Forest/home garden }\end{array}$} \\
\hline & Field $^{\mathrm{a}}$ & $\begin{array}{l}\text { Forest/home } \\
\text { garden }^{\mathrm{b}}\end{array}$ & Field $^{\mathrm{a}}$ & $\begin{array}{l}\text { Forest/home } \\
\text { garden }^{\mathrm{b}}\end{array}$ & \\
\hline Seedling & 2.59 & 4.64 & 1.10 & 0.65 & - \\
\hline Manure (as fertilizer) & 8.60 & 3.11 & 58.42 & 54.32 & 5.17 \\
\hline Urea & 4.65 & 2.87 & 3.96 & 2.16 & 0.31 \\
\hline Triple super phosphate & 2.70 & 2.81 & 1.78 & 2.73 & 0.39 \\
\hline Zwazelzurre ammoniac & 0.71 & 0.46 & 1.76 & 0.00 & 2.47 \\
\hline Ponska & 1.47 & 1.44 & 3.19 & 0.00 & 0.54 \\
\hline Pesticides & 1.65 & 0.38 & 2.01 & 0.00 & 0.64 \\
\hline Labor & 6.44 & 6.76 & 9.53 & 0.94 & 0.00 \\
\hline $\begin{array}{l}\text { Other (e.g. transportation cost, } \\
\text { electricity, water, diesel) }\end{array}$ & 2.88 & 0.06 & 4.03 & 0.17 & 0.64 \\
\hline Total costs & 31.68 & 22.53 & 85.79 & 60.95 & 10.15 \\
\hline
\end{tabular}

aAlso called "sawah" is a wet-open parcelized area that surrounded by hedges, located in steep slope and need a large quantity of water for irrigation. On the field/sawah rice is grown in rainy season and different crop such as maize, soybean and peanut normally planted during dry season

${ }^{\mathrm{b}}$ Home garden (Pekarangan) is a parcelized area that located close to settlement (house), it has no source of irrigation, managed non intensively either as agroforestry subsystem or monoculture. Sometimes "home gardens" are used as secondary field to grow maize, paddy, trees etc

\section{Results}

\section{Descriptive Statistics}

Responses from 172 farmers show that, on average, heads of household managing cut-and-carry parcelized agroforestry systems were $54.6(\mathrm{SD}=12.1)$ years old, with $25.6(\mathrm{SD}=13.4)$ years of farming experience (Table 5). On average, cut-and-carry agroforestry farmers had 1.9 AUs, two family members engaged as farm labor, and were more likely to live in higher elevations ( $>200-700 \mathrm{~m}$ above the sea level) and a farther travel time to the nearest market (27.4 min). Heads of households engaged in parcelized monocrops were slightly older with an average age of $55.1(\mathrm{SD}=11.8)$ years with $26.4(\mathrm{SD}=14.3)$ years of farming experience. The number of livestock units owned by monocrop farmers was also higher $(2.3$ AUs) than agroforestry farmers. The former mostly lived at lower elevation areas (0-200 $\mathrm{m}$ above sea level) suggesting better access to markets (16.6 min travel distance to nearest market). Among monocrop farmers, $72 \%$ were members of a cash and crop cooperative. Regarding land size ownership, both agroforestry and monocrop farmers managed slightly more than 1 ha of land with partiallyowned status (58.1\%) - i.e. the land is owned by another party but the farmer has the legal right to use the land under certain conditions. A majority of farmers had parcelized land consisting of more than one plot. Most agroforestry farmers $(70.3 \%)$ had two plots consisting of state-owned forest $(74.6 \%$ of the total land area) and community forest (25.4\% of total land area). Over a quarter of 
Table 5 Descriptive statistics comparing cut-and-carry parcelized agroforestry and monocrop systems $(n=172)$

Independent variable

Agroforestry $(n=122)$

Mean

(SD)

$\begin{array}{ll}0.26 & 0.68 \\ \text { (NA) } & \text { (NA) } \\ 27.43 & 16.60 \\ (16.10) & (12.82)\end{array}$

Farming and market information

Cash-crop cooperative membership

Accessibility to nearest market

Farm and land characteristics

Number of farm laborers

$$
1.29
$$

1.89

1.07

(0.30)

Land size

Land ownership status

Fully owned*

Partially owned*

Leased*

Elevation

Elevation 3*

Elevation 2*

Elevation 1*

Farmers demographic characteristics

Age (years)

Head of household highest education

Farming experience (years)

On-farm income
0.22

(NA)

0.68

(NA)

0.09

(NA)

0.27

(NA)

0.34

(NA)

0.37

(NA)

54.62

(12.15)

2.47

(.94)

25.60

(13.36)

2.02

(0.22)
Monocrop $(n=50)$

Mean

(SD)

0.68

16.60

1.16

2.33

(1.86)

1.18

(.422)

0.64

(NA)

0.30

(NA)

0.06

(NA)

0.36

(NA)

0.40

(NA)

0.24

(NA)

55.10

2.76

(1.01)

26.37

(1.86)

1.86

(0.45)

*Mean value denoting percent (\%); NA not applicable for categorical variables

${ }^{\dagger}$ AUs converted to categorical variable as per Table 3

commodity monocrop farmers $(28.5 \%)$ had more than 1 plot of land consisting of agricultural fields $(58.0 \%)$ and state forest $(42.0 \%)$.

Both cut-and-carry parcelized agroforestry and monocrop farmers had an average family-size of four individuals with at least one member working on the farm. 
On average, the head of the household of both groups had completed elementary schooling (at least 8 years of education). Farmers also engaged in off-farm income generating activities such as government employment, work as head of village, and traders. Off-farm income activities contributed an average annual income of US $\$ 94-U S \$ 500$ or $9.5 \%$ to $37.5 \%$ of total income.

\section{Logistic Regression and Propensity Score Matching}

The logistic regression offered a systematic comparison of associations between covariates denoting livelihood capitals and the likelihood of adopting parcelized agroforestry practices within cut-and-carry systems (Table 6). Results show a model that was highly statistically significant $(p<0.01)$. The analysis shows that explanatory variables gives an improvement of over $43 \%$ from the null model including solely an intercept. Variables capturing accessibility to the nearest market and land ownership status showed strong statistical associations $(p<0.01)$ with the adoption of parcelized agroforestry. Absolute marginal effects show that farmers who had full land ownership status where 8.36 times more likely to engage in agroforestry practices than those with other tenure conditions (e.g. partially owned, leased or

Table 6 Results of logistic regression assessing the likelihood of parcelized agroforestry adoption, over monocropped parcels, within cut-and-carry systems $(n=150 *)$

\begin{tabular}{|c|c|c|c|}
\hline Variable & Coefficient & Odds ratio & $p$ value \\
\hline \multicolumn{4}{|l|}{ Farming and market information } \\
\hline Cash-crop cooperative membership & -1.723 & 0.178 & 0.011 \\
\hline Accessibility to nearest market & 0.099 & 1.104 & $<0.001$ \\
\hline \multicolumn{4}{|l|}{ Farm and land characteristics } \\
\hline Number of farm laborers & -0.371 & 0.689 & 0.586 \\
\hline Livestock owned & -0.442 & 0.642 & 0.447 \\
\hline Land size & -0.143 & 0.866 & 0.827 \\
\hline Fully-owned land ownership status ${ }^{\dagger}$ & 2.123 & 8.360 & $<0.001$ \\
\hline Elevation $3^{\ddagger}$ & 1.708 & 5.522 & 0.040 \\
\hline Elevation $2^{\ddagger}$ & 1.677 & 5.349 & 0.045 \\
\hline \multicolumn{4}{|l|}{ Sociodemographic characteristics } \\
\hline Age & -0.011 & 0.988 & 0.655 \\
\hline Head of household highest education & -0.813 & 0.443 & 0.141 \\
\hline Farming experience & 1.329 & 3.778 & 0.065 \\
\hline On-farm income & 1.779 & 5.928 & 0.032 \\
\hline Constant & -7.929 & $<0.001$ & 0.003 \\
\hline Log-likelihood ratio $\left(\operatorname{Prob}>\chi^{2}\right)$ & $74.97(p<.001)$ & & \\
\hline Pseudo- $\mathrm{R}^{2}$ & 43.09 & & \\
\hline-2 Log likelihood & 49.503 & & \\
\hline
\end{tabular}

*Fewer observations included in regression due to incomplete questionnaires

†As compared to base level of 'other categories' (partially-owned, shared and leased)

${ }^{\ddagger}$ As compared to base level 'Elevation 1' 1 (0-200 m above sea level) 
shared plots). In addition, elevation and on-farm income showed strong statistical associations at the 5\% Type-I error level. For instance, medium and high elevations were associated with increased likelihood of agroforestry adoption by 5.52 and 5.35 times, respectively, over parcelized monocrop farmers. Higher income categories were also associated with the adoption of agroforestry practices. In contrast, cash crop cooperative membership, number of farm laborers, land size, having more than 2 AUs, and education had an inverse association with the likelihood of adopting agroforestry practices. Among the latter, membership in a cash crop cooperative was associated with odds ratio of farmers engaging in agroforestry practices being $82.8 \%$ lower than managing parcels as monocrops. Results show that the head of household's age and education attainment did not systematically differ between agroforestry and commodity agricultural farmers $(p>0.10)$.

The propensity score matching offered statistical evidence of the likely causality between the adoption of parcelized agroforestry and higher on-farm income levels than parcelized monocrops. Engagement in parcelized agroforestry significantly $(p<0.001)$ increased the likelihood of being in a higher income category by $14.0 \%$ (Coefficient for differences in means $=0.14$; std. error $=0.044$ ).

\section{Financial Analysis}

Total income per household was relatively small. Average on-farm income among parcelized agroforestry farmers was IDR 12 million/year, higher than on-farm income of monocrop farmers (US\$ 840/year compared with US\$ 756/year) in 2017. This difference is largely the result of different revenue levels from farming activities other than livestock; agroforestry systems prioritize agricultural crops and timber, while monocrops solely prioritize agricultural crops. Area-adjusted income from cash crops suggests farmers obtained US\$103.82 in profit per 0.1 ha if they plant rice in irrigated fields. Profits were lower if irrigated rice was planted on woodlots or in home garden areas. On average, a farmer earned US $\$ 44.80$ per harvest period. Yields and income from rice cultivation is affected by land and water characteristics and requirements, soil fertility, paddy infrastructure, tenure restrictions, and competition adjacent and associated crops (Roshetko et al. 2018).

Maize and ground nuts earned farmers around US\$41.18 and US\$98.78 of profits per 0.1 ha, respectively (Table 7 ). Revenue from livestock sales provided an additional $8.40 \mathrm{US} \$ /$ month to farmers with parcelized agroforestry systems and 8.05 US $\$$ /month to monocrop farmers. Results of the financial analysis show that households that managed timber and livestock in agroforested parcels had $11.1 \%$ higher on-farm income than those under a monocrop system corroborating results from the logistic regression and propensity score matching. 
Table 7 Cash-crop financial analysis for paddy, maize and groundnut farmed under agroforestry and monocrop practices (all values in US\$)

\begin{tabular}{lllll} 
Agroforestry & & & Monocrop \\
\cline { 1 - 3 } Pad0.1 ha) & Maize (0.1 ha) & $\begin{array}{l}\text { Groundnut } \\
(0.1 \text { ha })\end{array}$ & & Paddy (0.1 ha) Maize (0.1 ha)
\end{tabular}

\begin{tabular}{lrrrrr}
\hline Income & & & & & \\
Production & 183.50 & 546.00 & 134.00 & 369.30 & 144.00 \\
Price & 0.37 & 0.19 & 0.81 & 0.37 & 0.19 \\
Total income & 67.33 & 102.13 & 108.94 & 135.50 & 27.45 \\
Cost & & & & & \\
Seedling & 4.64 & 0.65 & 0.00 & 2.59 & 1.10 \\
Urea & 3.11 & 54.32 & 5.17 & 8.60 & 58.42 \\
Triple super & 2.87 & 2.16 & 0.31 & 4.65 & 3.96 \\
$\quad$ phosphate & & & & & \\
Zwazelzurre & 2.81 & 2.73 & 0.39 & 2.70 & 1.78 \\
$\quad$ ammoniac & & & & & \\
Ponska & 0.46 & 0.00 & 2.47 & 0.71 & 1.76 \\
Pesticide & 1.44 & 0.00 & 0.54 & 1.47 & 3.19 \\
Labor & 0.38 & 0.00 & 0.64 & 1.65 & 2.01 \\
Other (e.g. & 6.76 & 0.94 & 0.00 & 6.44 & 9.53 \\
$\quad$ transportation & & & & & \\
$\quad$ cost, electricity, & & & & & \\
$\quad$ water, petro- & & & & & \\
$\quad$ leum) & & 0.17 & 0.64 & 2.88 & 4.03 \\
Manure & 0.06 & 60.95 & 10.15 & 31.68 & 85.79 \\
Total cost & 22.53 & 41.18 & 98.79 & 103.82 & -58.34 \\
\begin{tabular}{l} 
Profit \\
\hline
\end{tabular} & 44.80 & & &
\end{tabular}

\section{Discussion}

Cut-and-carry agroforestry for confined livestock is a land management system used by farmers managing small-size plots. The extant literature describing this land management system is limited and a central aim of this study was to offer a detailed characterization of its features. As an alternative management approach, cut-andcarry agroforestry systems help minimize feed cost and utilize parcels under partial, shared and leased ownership. This system emphasizes the use of peripheral lands as source of fodder, cutting and carrying feed to a paddock near the farmer's house. A majority of farmers have parcelized land under full- or partial-ownership that allows the utilization of all holdings as sources of fodder. The implementation of cut-andcarry systems in Gunung Kidul also helps manage risks due of harvest failure by keeping livestock as an alternative income source in addition to timber. Nonetheless, we recognize that characteristics described in this manuscript represent conditions found in Indonesia's Gunung Kidul region and different practices are likely to occur in other regions. We offer our findings as a case study and stress the importance of 
continued research to better understand cut-and-carry systems and their prospective benefits to smallholders' resiliency.

From a sustainable rural livelihood capitals perspective our analysis sheds light on a number of matters. It is generally agreed that human capital has a direct and significant influence on farmers' decision to adopt innovative management practices (such as agroforestry) and technologies (Keelan et al. 2014; Mignouna et al. 2011). Franzel and Scherr (2002) explain that higher education has been associated with greater degrees of innovation and the adoption of agroforestry. Education is frequently noted to have a positive influence on farmers' adoption of new technology (Mignouna et al. 2011). Yongling (2004) posit that the lack of proper education can limit the capacity to distinguish between poor and good information. Results from our logistic regression show that farming experience was significantly and positively associated with the adoption of agroforestry practices. However, the age and education level of farmers had no significant association which is likely due to the fact that there were only slight differences between our two smallholder farmer groups-as a majority of farmers in Gunung Kidul have attained at least an elementary to junior high school education. Also related to human capital, farmers often allocate family labor to minimize farming costs (particularly the rearing of livestock). As a farm laborer in a cut-and-carry system, a family member is responsible for cutting and carrying fodder, feed cattle, manage trees, plant crops, clean paddocks and harvest timber and commodity crops, among other activities. The head of household does not pay wages to the family member; instead money is saved to meet other basic needs. Although it may be assumed that family labor is available the entire year, the need to earn more money at particular times leads family members to find offfarm jobs such as agricultural labor during the rainy season or casual employment in local towns in addition to net outmigration. However, the statistical association in our analysis was not significant which is likely a result of little variance between the two groups.

Regarding associations with social capital assets, we found that participation in a cash crop cooperative had a negative effect on the adoption of parcelized agroforestry practices. This association might be linked to how cash crop cooperatives emphasize information about markets and marketing of commodity crops. A more diverse farming system such as parcelized agroforestry inherently places a lower priority in such practices and, thus, was inversely associated with cash crop membership. Although farming information is commonly provided by the Indonesian government, farmers' land management decisions tend to be more directly influenced by information shared with fellow farmers, village leaders, and other peer groups. Martini et al. (2017) and Riyandoko et al. (2016) found that government extension services are inadequate to transfer agroforestry information and that farmer-to-farmer communication was the main channel used among smallholder farmers in central Java, Nusa Tenggara, and Sulawesi. Sunkar (2008) reported that farmers in Gunung Kidul undertake farming activities through inherited traditions, which have evolved over decades of experience, observation, and trial-and-error problem-solving. We posit that in our sample it was membership in cash crop cooperatives that facilitated information dissemination in regards to intensively managed monocrop farming having an inverse relationship with the adoption of parcelized agroforestry practices. 
Regarding financial capital, our findings show greater profits were accrued by parcelized agroforestry farmers. The likely causality between parcelized agroforestry and on-farm income was corroborated in results from the propensity score matching. Sabastian et al. (2014) explain that in Gunung Kidul larger land holdings devoting a greater area to timber production are associated with higher on-farm income. Our research suggests that by reallocating household labor and managing livestock, within a cut-and-carry system, co-located agroforestry practices can generate more on-farm income than monocropped parcels. Likewise, those implementing parcelized agroforestry were able to generate more income from livestock activities. Even though agroforestry farmers had fewer AUs than monocrop farmers, yet similar husbandry practices, the former generated more revenues from livestock ( $8.40 \mathrm{US} \$ /$ month compared with $8.05 \mathrm{US} \$ /$ month). We posit that greater profits might be the result of more efficient use of labor and other resources with fewer animals (e.g., farmers could provide healthier and more diverse diets by adding fodder from Pennisetum purpureum, Gliricidia sepium Leucaena leucochepala). Onfarm average income among farmers practicing parcelized agroforestry was higher by about $11 \%$, compared with those who managed parcels as monocrops, with statistical evidence of a causal effect. Farmers reporting higher off-farm income had a greater tendency to practice monocrop agriculture. Our data show that $77 \%$ of agroforestry farmers identified "farmer" as their main occupation and $11 \%$ had a secondary occupation, whereas among monocrop farmers $62 \%$ identified "farmer" as their primary job.

Adoption of parcelized co-located agroforestry practices was also associated with bio-physical capital assets. Comparing elevation, tenure rights, and travel distances to nearest market, farmers who owned land in higher altitudes, had land in full ownership, or experienced longer travel times had a greater likelihood of adopting parcelized agroforestry practices. We posit this happens because farmers (1) experience higher transportation costs from more remote plots, (2) a more challenging topography reflected in these variables can challenge the establishment of agriculture instead making tree planting more appealing, and (3) having full tenure rights can facilitate the establishment of long-term land practices. Longer travel times increase transaction costs and can reduce profitability of commodity crops often relying on thin profit margins. In the case of timber lots, although often experience greater profit margins, these are highly dependent on local supply chains where famers rely on traders or intermediaries to sell timber (Perdana and Roshetko 2015). Other site-specific characteristics such as soil fertility and topography can influence the adoption of farming practices on privately or leased lands. For instance, it is common for farmers to establish terraced landscapes and various silvicultural systems in lands of more difficult topography. Farmers in the Gunung Kidul region grow teak and acacia on steeper slopes, while mahogany has the best growth on gentle slopes (Sabastian et al. 2014). These trends are reflected on regional statistics as the higher altitude sub-districts of Paliyan and Panggang have the largest areas allocated to teak plantation at 2070 ha (40.0\%) and 1546 ha (29.8\%), respectively (Yogyakarta Department of Forestry 2017). Regarding land tenure systems and uses, teak plantations are often established within state-owned lands made available to smallholder farmers. This scheme gives smallholder farmers access to state land as part of 
the community-based forest management program implemented in Gunung Kidul. The government's Community Forest (Hutan Kemasyarakatan- HKm) scheme grants farmers 35-year usufruct rights to state forestland, with secured rights for forest products other than timber, and permission for timber production created through concession agreements with final profits co-shared with the government (Ota 2011). Due to limited rights to grow timber, farmers first produce agricultural crops on state forestlands when the canopy is still open and can harvest livestock fodder.

In the Gunung Kidul area, farmers treat livestock as a savings and risk management financial asset. Hence, it is logical that farmers keep livestock near their homes as a safety precaution. They buy livestock when they have cash-in-hand beyond immediate financial demands and sell it when in need. Timber trees are kept for savings in case for emergency cash situations. Farmers sell either livestock or timber trees anytime when they need cash; whether livestock or timber tree, they do not consider the best time to sell the standing asset to obtain the greatest financial return. Their main concern is to not experience a dramatic financial loss and obtain just enough money as immediately needed; which often results in smallholder farmers receiving below market prices from teak traders (Perdana and Roshetko 2015). Timber sale is often preceded by a sequence of liquidated assets. For instance, Perdana et al. (2012) found that Gunung Kidul farmers manage teak trees as financial reserves that are retained until other disposable assets such as motorcycles, jewelry and electronic devices have been sold. How farmers decide to fulfill their cash needs can be classified into three categories. First is that of high-stake financial needs, where farmers need a major sum of money for a specific purpose (e.g., to pay medical costs, construct/renovate house, buy a motorcycle or land). Farmers sell more than one goat/sheep, cattle or timber tree to cover this financial burden. A second category is that of medium financial needs. This category includes payments for schooling or to buy feed/fodder for livestock. Farmers usually sell goats/sheep and agricultural crops like maize and ground nut to obtain money for such demands. Paddy is the only product seldom sold by farmers as it is used as a staple food. Last, are small financial needs to fulfill basic daily demands. Farmers sell either poultry (e.g., a chicken, duck) and/or agricultural commodities (e.g. maize and ground nut) to cover such expenses.

Our results suggest that having full tenure over land made landowners more likely to implement parcelized agroforestry practices. This finding corroborates results from Roshetko et al. (2008) who reported that secure land and tree tenure rights are prerequisites for the development of smallholder agroforestry systems in Indonesia. Both categories of cut-and-carry farmers placed the paddock and livestock at the parcel where they have full, or most and well-defined, tenure rights. It was often the case that they were co-located in the plot where the household resided. As woodlots are in public jurisdiction, farmers utilized them for feed collection and not active livestock management, although on occasion they may graze on them. Farmers have adapted to, and a cut-and-carry system has partly emerged from, the array of property rights inherent to various farming resources ranging from land, to timber and livestock, and fodder (Barbieri and Aguilar 2011). 
Table 8 Synthesis of salient advantages and disadvantages of parcelized cut-and-carry system for confined livestock production

\begin{tabular}{|c|c|}
\hline Advantages & Disadvantages \\
\hline $\begin{array}{l}\text { Reduces livestock feed costs by sourcing forage } \\
\text { from woodlots and agricultural plots }\end{array}$ & $\begin{array}{l}\text { Requires adequate financial and land capitals for } \\
\text { confined livestock* in paddock }\end{array}$ \\
\hline $\begin{array}{l}\text { Improves financial resilience from farm diversifi- } \\
\text { cation, magnified under parcelized agroforestry } \\
\text { Reduces risk through farm diversification } \\
\text { Maintains and grows livestock* as a non-perisha- }\end{array}$ & $\begin{array}{l}\text { Demands labor often multiple times a day for fodder } \\
\text { collection and livestock management-alterna- } \\
\text { tively, requires paying labor costs for conducting } \\
\text { the same activities }\end{array}$ \\
\hline ble marketable product and financial instrument & Requires time-bound management as animals need \\
\hline $\begin{array}{l}\text { Tailors land use to plot-specific bio-physical and } \\
\text { land tenure conditions along suitable agronomic }\end{array}$ & $\begin{array}{l}\text { to be feed } 2-3 \text { times a day and pen needs to be } \\
\text { cleaned daily }\end{array}$ \\
\hline practices & Demands more time allocated to accessing various \\
\hline $\begin{array}{l}\text { Maximizes productivity of marginal and underu- } \\
\text { tilized peripheral farming niches (understories, }\end{array}$ & $\begin{array}{l}\text { farm plots than larger farms, farmers often rely on } \\
\text { motorcycles }\end{array}$ \\
\hline $\begin{array}{l}\text { terrace walls, borders, roadways) and underuti- } \\
\text { lized vegetation for fodder }\end{array}$ & $\begin{array}{l}\text { Requires access to private, public and community- } \\
\text { shared lands to source adequate fodder resources }\end{array}$ \\
\hline Reduces dependence on external farm outputs as & to effectively reduce feed costs \\
\hline $\begin{array}{l}\text { many fodder crops grow from natural regenera- } \\
\text { tion }\end{array}$ & $\begin{array}{l}\text { Requires in-depth farming knowledge and experi- } \\
\text { ence to manage multiple land uses, often limiting }\end{array}$ \\
\hline Recycles manure for organic fertilizer and com- & adoption by younger farmers \\
\hline & Needs adequate understanding and current informa- \\
\hline $\begin{array}{l}\text { Lowers demand for investments in a larger herd } \\
\text { size accommodating farmer's available resources }\end{array}$ & $\begin{array}{l}\text { tion of multiple markets, not relying on farming } \\
\text { cooperatives }\end{array}$ \\
\hline including labor and capital & Requires at least one or two plots for forage fod- \\
\hline $\begin{array}{l}\text { Integrates well with annual and perennial cropping } \\
\text { systems whether in a co-located agroforestry } \\
\text { system or not }\end{array}$ & $\begin{array}{l}\text { der-although some farmers also have it in their } \\
\text { back/front yard or near the shelter) }\end{array}$ \\
\hline
\end{tabular}

*We place greater emphasis on cattle as the main form of livestock asset managed under this system

Table 8 offers a synthesis of the apparent advantages and disadvantages identified from our characterization of cut-and-carry systems and particularly the adoption of parcelized agroforestry over monocrop lots. Our synthesis is offered from a smallholder farming perspective and, although comprehensive, is not deemed to be exhaustive as this is an area that warrants additional investigation. Various policy implications stem from our characterization. We stress that cut-and-carry systems adopted as parcelized agroforestry:

(1) offer an alternative to promote diversified and financially resilient farmingwhen management and usufruct of under-utilized public lands are granted under conditions that sustainable agronomic practices that are socially-acceptable by local communities;

(2) enhance on-farm revenues which are greater when it occurs in conjunction with co-located agroforestry practices - that can be supported through easier capital access to invest in livestock and dedicated woodlots; 
(3) demand a greater degree of farming and market knowledge-for which public extension and education programs might be necessary to support younger and lower-income farmers.

\section{Conclusions}

A cut-and-carry system integrates natural resource management over a landscape dominated by small-size parcels by cutting and carrying fodder to a paddock, and when animal manure is returned to the fields. Financial management is central to the adoption of cut-and-carry systems for confined livestock. The adoption of a cut-andcarry system supports farmers' financial resiliency by limiting cash expenditures (e.g. lower livestock feed expenditures) and facilitating income diversification (e.g. allocating land to different uses) that can help meet planned and unexpected cash demands. Farmers treat livestock and timber trees as savings and risk-management resources. Cut-and-carry systems in Gunung-Kidul have also partly emerged from the array of property rights associated with different farming resources (e.g., land, timber livestock, fodder) in private and shared ownership.

Within parcelized cut-and-carry agroforestry systems we distinguished between one land management approach where agroforestry practices are co-located in a traditional fashion often as wind breaks or tree fences, and another where agricultural and forestry practices may be implemented on specific parcels, such as cash monocrops and timber lots, yet integrated across land holdings. Face-to-face surveys conducted with farmers engaged in parcelized agroforestry and monocrop cut-and-carry systems determined that the former had more farming experience, greater on-farm income, with parcels located at higher elevations, and farther from the nearest market. Within our two categories of cut-and-carry farmers, those adopting parcelized co-located agroforestry had larger on-farm income-about $11 \%$ higher than agricultural farmers on a per-hectare basis. More diversified income sources likely contributed to this difference.

The adoption of parcelized co-located agroforestry was strongly associated with bio-physical livelihood assets. Specifically, farmers with land under full-ownership were 8.3 times more likely to adopt parcelized agroforestry over monocropped parcels; possibly facilitated by the ability of long-term planning that support tree planting. Having land at greater altitudes increased the odds of engaging in parcelized co-located agroforestry about 5 times over the implementation of monocrops. More challenging topography can be a deterrent to the adoption of monocrops that often required more intensive and often mechanized management. Longer travel distances to market also made farmers more likely to engage in parcelized agroforestry. Associated higher transportation costs can discourage the planting of commodity crops that often have to be brought timely to local markets at very thin profit margins. It was a social capital asset, as captured by membership in a cash-crop cooperative, that showed the greatest association with the likelihood of engaging in monocropped parcels; it decreased the odds of parcelized agroforestry by over $83 \%$. Sharing of agronomic knowledge and market information likely contributed to the planting of commodity crops in monocropped systems. 
Acknowledgements This research was supported by the Governing Oil Palm Landscapes for Sustainability project led by the Center for International Forestry Research (CIFOR) and the United States Agency for International Development (USAID). Ainun Seruni led data collection and initial analyses as a USAID/CIFOR scholar at the University of Missouri. This project was also partly funded by the US Department of Agriculture's National Institute of Food and Agriculture under McIntire Stennis agreement MO-MCNR005 and Project 1012779; and by the University of Missouri Center for Agroforestry/ US Department of Agriculture's Agricultural Research Service Dale Bumpers Small Farm Research Center under Agreement Number 58-6020-6-001. We would like to thank the World Agroforestry Center for research assistance under the project Developing and promoting market-based agroforestry options and integrated landscape management for smallholder forestry in Indonesia funded by the Australian Centre for International Agricultural Research. We stress our appreciation to farmers who participated in this research and enumerators who helped conduct face-to-face surveys.

Funding Open access funding provided by Swedish University of Agricultural Sciences.

Open Access This article is licensed under a Creative Commons Attribution 4.0 International License, which permits use, sharing, adaptation, distribution and reproduction in any medium or format, as long as you give appropriate credit to the original author(s) and the source, provide a link to the Creative Commons licence, and indicate if changes were made. The images or other third party material in this article are included in the article's Creative Commons licence, unless indicated otherwise in a credit line to the material. If material is not included in the article's Creative Commons licence and your intended use is not permitted by statutory regulation or exceeds the permitted use, you will need to obtain permission directly from the copyright holder. To view a copy of this licence, visit http://creativecommons.org/licen ses/by/4.0/.

\section{References}

Adesina AA, Chianu J (2002) Determinants of farmers; adoption and adaptation of alley farming technology in Nigeria. Agrofor Syst 55:99-112

Alavalapati JRR, Shrestha RK, Stainback GA, Matta JR (2004) Agroforestry development: an environmental, economic perspective. Agrofor Syst 61-62:9-310

Anbumozhi V, Jay R, Eiji Y (2005) Impact of riparian buffer zones on water quality and associated management considerations. Ecol Eng 24:517-523

Barbieri C, Aguilar FX (2011) Thinking beyond property rights and open access: the Ius In Re as a framework for developing tenure institutions for renewable natural resources. Soc Nat Resour 24:292-302

Baum FE, Ziersch AM (2003) Social capital. J Epidemiol Community Health 57:320-323

Cai Z, Aguilar FX (2013) Consumer purchasing preferences and corporate social responsibility in the wood products industry: a conjoint analysis in the U.S. and China. Ecol Econ 95:118-127

Central Bureau of Statistics Republic of Indonesia (2016) Informasi Terbaru. https://www.bps.go.id/

Coleman JM (2010) Social capital in creation of human capital. Am J Sociol 94:95-120

Daly H, Cobb Jr. JB, Cobb JB (1994) For the common good: redirecting the economy toward community, the environment, and a sustainable future (No. 73). Beacon Press, Boston

Dehejia R, Wahba S (2002) Propensity score-matching methods for nonexperimental casual studies. Rev Econ Stat 84(1):151-161

Der Poel Van, Dijk Van (1987) Household economy and tree growing in upland Central Java. Agrofor Syst 5(2):169-184

Ellis F (1998) Household strategies and rural livelihood diversification. J Dev Stud 35(1):1-38

Ellis F (1999) Rural livelihoods diversity in developing countries: evidence and policy implications. Natural Resource Perspectives 40. London: DFID

Ellis F (2000) The determinants of rural livelihood diversification in developing countries. J Agric Econ 51(2):289-302

Franzel S, Scherr SJ (eds) (2002) Trees on the farm: assessing the adoption potential of agroforestry practices in Africa. CABI, Wallingford 
Fujiwara T, Awang S, Widayanti W, Septiana R, Hyakumura K, Sato N (2018) Socioeconomic conditions affecting smallholder timber management in Gunungkidul District, Yogyakarta Special Region, Indonesia. Small-Scale For 17:41-56

Gintings AN, Lai CK (1994) Agroforestry in Asia and the Pacific: with special reference to silvopasture systems. ACIAR proceedings, pp 32-38

Gittinger JP (1982) Economic analysis of agricultural projects, 2nd edn. Johns Hopkins University Press, Baltimore

Green GP, Haines A (2002) Asset building \& community development. SAGE Publication, California

Haines A, McFarane D (2007) Understanding landscape fragmentation and parcelization: an examination of traditional planning tools. Proceeding of 48th annual conference of the American Collegiate Schools of Planning Milwaukee, WI. http://dx.doi.org/10.5716/WP16141.PDF

Hosmer D, Lemeshow S, Studivarnt R (2013) Applied logistic regression, 3rd edn. John Wiley \& Son Inc, Hoboken

Keelan C, Thorne F, Flanagan P, Newman C (2014) Predicted willingness of Irish farmers to adopt GM technology. AgBioForum 12(3\&4):394-403

Law No 19/(2013) Law on the protection and empowerment of farmers. 06 August 2013.Indonesia

Martini E, Roshetko JM, Paramita E (2017) Can farmer-to-farmer communication boost the dissemination of agroforestry innovations? A case study in Sulawesi, Indonesia. Agrofor Syst 91(5):811-824. http://link.springer.com/article/10.1007/s10457-016-0011-3

McCabe C (2013) Agroforestry and smallholder farmers: climate change adaptation through sustainable land use. Capstone Collection 2612

McGinty M, Swisher M, Alavalapati J (2008) Agroforestry adoption and maintenance: self-efficacy, attitudes and socio-economic factors. Agrofor Syst 73:99-108

Mignouna B, Manyong M, Rusike J, Mutabazi S, Senkondo M (2011) Determinants of adopting imazapyr-resistant maize technology and its impact on household income in Western Kenyaa. AgBioforum 14(3):158-163

Missemer A (2018) Natural Capital as an economic concept, history and contemporary issues. Ecol Econ 143:90-96

Monke E, Pearson SR (1989) The policy analysis matrix for agricultural development. Cornell University Press, Ithaca

Neupane RP, Khem RS, Gopal BT (2002) Adoption of agroforestry in the hills of Nepal: a logistic regression analysis. Agric Syst 72(3):177-196

Nibbering JW (1999) Tree planting on deforested farmlands, Sewu Hills, Java, Indonesia: impact of economic and institutional changes. Agrofor Syst 57:173-186

Ota M (2011) Implementation of the community forest (hutan kemasyarakatan) scheme and its effects on rural households in Gunung Kidul district, Java, Indonesia: an exploration of the local agrarian context. Tropics 19(3):123-133

Pattanayak SK, Mercer DE, Sills E, Yang JC (2003) Taking stock of agroforestry adoption studies. Agrofor Syst 57(3):37-150

Perdana A, Roshetko JM (2015) Survival strategy: traders of smallholder teak in Indonesia. Int For Rev 17(4):461-468

Perdana A, Roshetko JM, Kurniawan I (2012) Forces of competition: smallholding teak producers in Indonesia. Int For Rev 14(2):238-248

Pincay-Figueroa PE, Lopez-Gonzales F, Velarde-Guillen J, Heredia-Nava D, Martinez-Castaneda F, Vicente F, Martinez-Fernandez A, Arriaga-Jordan C (2016) Cut and carry versus grazing of cultivated pastures in small scale dairy systems in the central highlands of Mexico. J Agric Environ Int Dev 110(2):349-363

Riyandoko, Martini E, Perdana A, Yumn A, Roshetko JM (2016) Existing conditions, challenges and needs in the implementation of forestry and agroforestry extension in Indonesia. Working Paper no. 238. World Agroforestry Centre (ICRAF) Southeast Asia Regional Program, Bogor, Indonesia

Rohadi D, Roshetko JM, Perdana A, Blyth M, Nuryartono N, Kusumowardani N, Pramono AA, Widyani N, Fauzi A, Sasono J, Sumardamto P, Manalu P (2011) Improving economic outcomes for smallholders growing teak in agroforestry systems in Indonesia. Final report of project FST.2005/177, Australian Centre for International Agricultural Research, Canberra

Roshetko JM, Snelder DJ, Lasco RD, and van Noordwijk M (2008) Future Challenge: a paradigm shift in the forestry sector. In: Snelder DJ, Lasco RD (eds) Smallholder tree growing for rural development and environmental services, pp 453-485 
Roshetko JM, Rohadi D, Perdana A, Sabastian G, Nuryartono N, Pramono AA, Widyani N, Manalu P, Fauzi MA, Sumardamto P, Kusumowardhani N (2013) Teak agroforestry systems for livelihood enhancement, industrial timber production, and environmental rehabilitation. For Trees Livelihoods 22(4):241-256

Roshetko JM, Finlayson R, Öborn I, Sabastian G, Perdana A, Martini E, Mulyoutami E, Mercado Jr. A, Jamieson C, Simelton E, Sinclair F, Wangpakapattanawong P, Ratnamhin A, Prameswari D, Ekawati D, Shono K (2018) Agroforestry in rice-production landscapes in Southeast Asia. Policy Brief no. 90. Agroforestry options for ASEAN series no. 6. Bogor, Indonesia: World Agroforestry Centre (ICRAF) Southeast Asia Regional Program; Jakarta, Indonesia: ASEAN-Swiss Partnership on Social Forestry and Climate Change; Bangkok, Thailand: Food and Agriculture Organization of the United Nations Regional Office for Asia and the Pacific

Sabastian GE, Roshetko JM, Anggakusuma D, Pramono AA, Heriansyah I, Fauzi A (2009) Smallholder teak-based farming management in Gunung Kidul, Yogyakarta: current Agroforest Syst practice, obstacles and improvement options. ACIAR Project Report, Australian Centre for International Agricultural Research, Canberra, and World Agroforestry Centre Southeast Asia Regional Program, Bogor, Indonesia

Sabastian GE, Kanowski P, Race D, Williams E, Roshetko JM (2014) Household and farm attributes affecting adoption of smallholder timber management practices by tree growers un Gunung Kidul region, Indonesia. Agrofor Syst. https://doi.org/10.1007/s10457-014-9673-X

Sabrani A, Saepudin Y (1994) Agroforestry, resettlement and shifting cultivation. Proceeding of AAAP Animal Science Congress, Bali, Indonesia. Canberra: Australian Centre for International Agricultural Research

Smith R, Simard C, Sharpe A (2001) A proposed approach to environment and sustainable development indicators based on capital. The national round table on the environment and the economy's environment and sustainable development indicators initiative, Canada. https://www.oecd.org/site/world forum/33626361.pdf

Song N, Aguilar FX, Butler BJ (2014a) Conservation Easements and Management by family forest owners: a propensity score matching approach with multi-imputations of survey data. For Sci 60(2):298-307

Song N, Aguilar FX, Butler BJ (2014b) Cost-share program participation and family forest owners' past and intended future management practices. For Policy Econ 46:39-46

Statistics of Gunung Kidul Regency (2009) Gunungkidul in figures 2009.BPS—Statistics of Gunungkidul Regency, Wonosari, DIY

Statistics of Gunung Kidul Regency (2016) Gunungkidul in figures 2016. BPS - Statistics of Gunungkidul Regency, Wonosari, DIY

Sudiharjo AM, Notohadiprawiro T (2006) Sekuen produktivitas lahan di wilayah karst Karangasem, Kecamatan Ponjong. Ilmu Tanah Universitas Gadjah Mada, Yogyakarta

Sunkar A (2008) Deforestation and rocky desertification processes in Gunung Sewu karst landscape. Media Konservasi 13(3):1-17

Van Noordwijk M, Pendo MS, Thomas PT, Chimere D, Steve V (2001) Land use Practice in the Humid Tropics and Introduction to ASB Benchmark Areas. International Centre for Research in Agroforestry Southeast Asia Regional Research Programme, Bogor

Yogyakarta Department of Forestry (2017) Management plan of forest management unit in Yogyakarta. Yogyakarta Department of Forestry, Yogyakarta

Yongling Z (2004) Information service in rural China field surveys and findings. FAO, Bangkok

Publisher's Note Springer Nature remains neutral with regard to jurisdictional claims in published maps and institutional affiliations. 


\section{Affiliations}

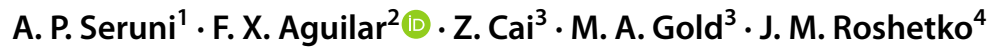

1 Perkumpulan Lingkar Pembaharuan Desa dan Agraria, Yogyakarta, Indonesia

2 Department of Forest Economics, Swedish University of Agricultural Sciences, Umeå, Sweden

3 The School of Natural Resources, University of Missouri, Columbia, MO, USA

4 World Agroforestry Center, Bogor, Indonesia 